\title{
Job Hopping Tendency In Millenials
}

\author{
Dhruba Lal Pandey, Ph.D. \\ Associate Professor \\ Central Department of Management, T.U.
}

\begin{abstract}
Job hopping refers to the tendency of a person to work briefly in an organization in particular position rather than staying in an organization for a longer time. This research study is conducted to examine the job hopping tendency in millennial in private sector of Nepal. It also studies the factors which attracts millennial in new organization. The factors which force a person to leave an organization are to seek new opportunities. Generally the considered variables for leaving the job; low pay structure, low potential for growth, and unfair treatment by management and conflict with the immediate supervisor/Coworkers. The factors considered for choosing the new job; chances of career growth, higher salary, job security, freedom at workplace, reputation of organization and higher position.

Materials and methods: Study populations are the millennial working in private organizations of Kathmandu valley. For this study the convenience sampling method was chosen where the data was collected through the questionnaire. Data were collected using likert scale questionnaire, yes/no questions, multiple choice single response and multiple choice multiple response questions. Percentage and correlation matrix was used to analyse the data.

Results: The outcome of the research indicates that main reason behind millennial leaving the organization is no growth opportunity and attraction towards new job is career growth. The employees chose the current organization either they are getting higher position or sensize future growth.

Keywords: Millennial, Job hopping, Job Switching
\end{abstract}

\section{Introduction}

Job Hopping is a tendency of switching over jobs in a given period of time. We hardly get to hear that person who started their career at entry position in an organization retired from the same organization. So, this is a common practice of employees in private organization and this practice is seen more in Millennial than in any other generations. The reason behind hopping the job is that employees do not believe that staying in one job would give huge opportunities like financial gain or career advantage than switching to other job. With advancement of technology, transportation and globalization, more opportunities are around the corners of the world. This has also been the major reason behind why people leave the jobs.

It is easy nowadays to hop online and search the jobs. Since there are more online job portals available in Nepal like Merojob.com, Hamrojob.com, Kumarijobs.com, Apply job, Job Dynamics, etc. where anyone can apply for the job within a single click. Job Hopping practice is increasing day by day. Nowadays it is hard for the employers to sustain their job-hopping employees. But reasons for such behavior by these jobhoppers are motivated by several factors.

This study is an attempt on understanding the reasons behind the job-hopping tendency in Millennial of Nepal and examines the relationship between predictor variables and job hopjng. 


\section{Theoretical Framework}

For the first time, March \& Simon (1958) discussed about the different factors that affects the employees' desire to stay with or leave the company. Later, other researches contributed in the literature. Porter-Steers (1973) developed met expectation hypothesis which described 3 common denominators to describe an individual's motivation to stay in an organization. It includes organization related factors (pay and promotion, organization size and job security), job environment factors (supervisory style, work unit size ,nature of peer group interaction), Job content factors ( nature of work, job stress and repetitiveness, job autonomy and responsibility, role ambiguity and conflict) and personal factors (Personality, age, tenure) within an organization). Researches like Lee, Mitchell, Sablynski, Burton, \&Holtom, (2004); Mitchell, Holtom, Lee, Sablynski, \& Erez, (2001) have examined how employee embeddedness can influence their desire to leave, either from the employees' perceptions of how well they fit with their jobs or from the organizations perception of how well the employee is performing and adapting. Other researchers; Maertz\& Campion, (2004) \& Maertz \& Griffeth, (2004) have also examined various motivational factors that influence employees' desire to stay with the company. These factors include organization-related aspects, such as employees enjoying the jobs they hold, liking the organizations for which they work, or wanting to continue working with coworkers with whom they have close relationships. These factors also include individual-related aspects, such as feeling of moral obligation towards their employer, an innate sense of responsibility, or even their personal habit of committing to the things they choose. Some of these factors that influence the employees' desire to quit or stay can only be determined after they start working but some of the factors can also be determined at the time of the recruitment process. So, further researches were concerned with the pre-hire attributes that influence the likeliness of the applicants to stay with the organization for the long time. They also suggested that predictors that influence retention also influence their motivation to perform well in their jobs.

Thus, the predictors used in this study are determinants of job hopping. The predictors which have used for this study:

Management style
$>\quad$ Relationship with subordinates and
colleagues
$>$ Relationship with superior/boss
$>\quad$ Reb security

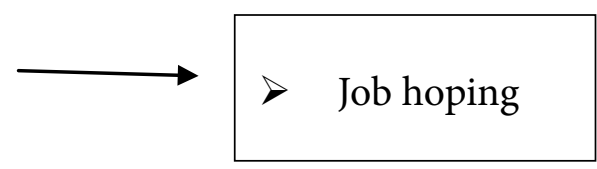

\section{Research Methodology}

The main purpose of this study is to find out the reason of job hopping in Millennial in Nepal on the basis of Gender, Age group, Marital Status, Family type and the Sector they are currently engaged in. A descritive analysis was carried out to achieve this objective. The research is a quantitative in nature. Primary as well as secondary data sources have been considered while conducting study. For primary sources, questionnaire was used.

\section{Population and Sample}

The population for this study is considered to be all the Millennial working in private organizations in Kathmandu valley. From the research report of previous studies that we have considered the sample sizes were low. Thennakoon (2001) has taken 30 samples out of which 25 were generation Y employees and 5 were the managers of the respective organization. Krishnan, Miranda, \& Siddiq (2014) considered 
Vol. 4, No. 1

194 samples. This study has taken 200 samples which is more than the sample taken in the previous similar studies.

\section{Research Instrument}

The instrument used for the study is questionnaire. The questionnaire included 16 questions that included categorical questions. Questionnaire consists of various domains related to job hoping. Multiple Choice questions, Likert Scale and Yes/No questions, were used.

\section{Data Analysis}

Collected data's reliability was tested calculating alpha value. Alpha value indicating the reliability for Management style is .727, Relationship with subordinates and colleagues is .775, Relationship with superior/boss is .700, Job security is .906 and Reputation of the organization is .822. Kervin (1992) suggested that the alpha value greater than .7 is sufficient for further analysis. Thus, the alpha values of all independent variables are greater than .7. So, it is claimed that overall reliability of all factors are sufficient for further analysis.

The collected data has been analyzed by using statistical tools; frequency, percentage, correlation matrix were used to analyse the data. Frequency has been used to see the number of Millennial who choose the job under different domains. Percentage has been used to see the ratio of job hoping Millennial under different domains and correlation matrix is used to see the relationship between Management style Relationship with subordinates and colleagues, Relationship with superior/boss, Job security and Reputation of the organization and job hoping.

\section{Nature of Job Hopping}

\section{Results and Findings}

In this study we have found that, majority of job hoppers are male. Out of 200 respondents surveyed, $67.5 \%$ of males have left their job whereas it is just $32.5 \%$ in females. On the basis of marital status, $82.5 \%$ of the respondents were unmarried and $17.5 \%$ were married. So, it shows that job hopping tendency is more in unmarried people in comparison to married ones. Out of total 200 millennial respondents $50 \%$ were born in year of 1994-1996, followed by 37\% of respondents born in year 1989-1993 and $5 \%$ number of respondents in the birth year of 1981-1984.On the basis of job sector the majority of respondents i.e. 37 $\%$ of this study belonged to banking sector , $21.5 \%$ belong to the education sector . Hydropower, Medical, Itch, Ngo and Business sectors are other sectors from which respondents were selected..

\section{Reasons of job hopping in Millennial}

The most selected reason behind leaving the previous job is for seeking better opportunities. Employees in Nepal seemed to be highly concerned about the opportunities in the workplace, and if they seek no better opportunities they are likely to leave the organization. Out of 200 respondents $27.2 \%$ switched their current job for better opportunities.

The second most important reason behind employees switching to new job is because of low pay structure in current job. In case of Nepal money is also considered to be symbol of status, so millennial prefer to have higher salary and financial incentives. $24.9 \%$ of respondents left their previous job because of the low pay structure.

The third major reason which influences Millennial to leave the organization is poor perspective of growth in their current job. It means that Millennial not only want to earn higher salary but also they seek their career growth in the organization. And this can be explained by the fact that $16.8 \%$ of the respondents have chosen this reason behind their job switch.

Another reason behind switching the current job is low job security. The jobs in private organizations 
are not stable as compared to the government jobs. The employees do not know when they will be fired from the organization where they are working. That is the reason why employees are engaged in Job Hopping. According to our survey report $11.6 \%$ of respondents feel that they had no job security in their previous organization where they were working. Thus they quit the job.

Migrations of employees and conflict with the immediate supervisor or coworker are the other reasons why Millennial leave their job in Nepalese context. It has been found that $6.1 \%$ of respondents have left their job because of migration and $4.6 \%$ have left because of conflict with immediate supervisor/coworker.

\section{Factors those pull millennial to a new organization}

The first factor considered by an employee while joining a new organization is perspective of career growth. The employees chose the current organization because they got higher position or saw future growth. $42 \%$ of the respondents consider career growth as the major reason of joining a new organization.

The second factor that the employees consider is higher salary. It means that respondents' second most reason to leave an organization is because they got low salary structure. The second reason they would look from other organization to join is the higher salary.

The other factors the Millennial consider while selecting a new organization are Job Securities, freedom at workplace, reputation of the organization and higher post. $9.5 \%$ of respondents have considered that their new job is more secured and offer them higher position. $8.5 \%$ and $6 \%$ of respondent's reason was reputation of the organization and freedom at the workplace respectively.

Test of multicollinearity regressing determinants of job hoping and job hoping using collinearity statistics has been conducted. The value of VIF factor is 1.139, 2.043, 2.216, 2.770 and 1.282 for the variables Management style, relationship with subordinates and colleagues, relationship with supervisors, job security and reputation of the organization. Theory of statistics suggested that If the VIF value is less than 5 , independent variables are not strongly correlated and thus, there is no multicollinearity. All the VIF values of all independent variables are less than 5 . Thus, it can be claimed that there is no multicollinearity.

\section{Findings of the Predictors and Job Hopping}

The first hypothesis has been supported which states that there exists significant relationship between management style and job hopping. It means that if management style is democratic, the rate of job hopping among Millennial will be low.

The second hypothesis has also been supported which states that the formal relationship with subordinates and colleagues has significant relationship with job hopping. If employees have informal relationship with the subordinates and colleagues, there is low job hopping and vice versa.

The third hypothesis has also been supported which states that the formal relationship with superior and boss has significant relationship with job hopping. If employees have informal relationship with the superior and boss, there is low job hopping and vice versa.

The fourth hypothesis has also been supported which states that job security has significant relationship with job hopping. If employees have high job security, then the probability of employees leaving the job is low and vice-versa.

The fifth hypothesis has also been supported which states that there exists significant relationship between reputation of the organization and Job hopping. The employees' chances of staying in a reputed organization are comparatively higher than in a low reputed organization. 


\begin{tabular}{|c|c|c|c|c|c|c|}
\hline \multicolumn{7}{|c|}{ Relationship between job hoping domains and job hoping of Millennial } \\
\hline & $\begin{array}{c}\text { Management } \\
\text { style }\end{array}$ & $\begin{array}{l}\text { Relationship with } \\
\text { my subordinates } \\
\text { and colleagues }\end{array}$ & $\begin{array}{l}\text { Relationship with } \\
\text { my superior and } \\
\text { boss }\end{array}$ & $\begin{array}{c}\text { Job } \\
\text { security }\end{array}$ & $\begin{array}{c}\text { Reputation of } \\
\text { organization }\end{array}$ & $\begin{array}{c}\text { Job } \\
\text { hopping }\end{array}$ \\
\hline \multirow{2}{*}{$\begin{array}{l}\text { Management } \\
\text { style }\end{array}$} & 1 & $.323^{* *}$ & $.393^{* *}$ & .096 & $.298^{* *}$ & $.635^{* *}$ \\
\hline & & .000 & .000 & .179 & .000 & .000 \\
\hline \multirow{2}{*}{$\begin{array}{l}\text { Relationship } \\
\text { with my } \\
\text { subordinates } \\
\text { and colleagues. }\end{array}$} & & 1 & $.493^{* *}$ & $.216^{* *}$ & $.244^{* *}$ & $.650^{* *}$ \\
\hline & & & .000 & .002 & .000 & .000 \\
\hline \multirow{3}{*}{$\begin{array}{l}\text { Relationship } \\
\text { with my } \\
\text { superior and } \\
\text { boss. }\end{array}$} & & & 1 & $.343^{* *}$ & $.316^{* *}$ & $.735^{* *}$ \\
\hline & & & & .000 & .000 & .000 \\
\hline & & & & & & \\
\hline \multirow{2}{*}{ Job security } & & & & 1 & $.521^{* *}$ & $.646^{* *}$ \\
\hline & & & & & .000 & .000 \\
\hline \multirow{2}{*}{$\begin{array}{l}\text { The reputation } \\
\text { of organization }\end{array}$} & & & & & 1 & $.705^{* *}$ \\
\hline & & & & & & .000 \\
\hline Job hopping & & & & & & 1 \\
\hline
\end{tabular}

The $\mathrm{p}$ value of all the variables are 0.000 as shown in correlation matrix. Since p-value $<$ level of significance. So, predictors have significant relationship with job hopping.

Multiple regression model has been used to analyse the results as;

Job hoping $=a+b$ management style $+b$ relationship with subordinates $+b$ relationship with superiors $+b$ job security $+b$ reputation of organization

Beta value and p-value are calculated as, $1.247(.000), 0.41(.001), .606(.002), .11(.0067)$ and $.257(.000)$.

Regression result also confirms to the relationship presented by the correlation matrix. Thus, it can be claimed that Nepalese millineals Prioritizes to the other factors more than the job security while hoping the job.

\section{Conclusion and Implication}

According to the findings of the study, the average number of years a Millennial would stay in an organization is 1 year. The findings of our study contradicts with the findings of Thennakoon, (2014) that the aveage number of year that a employee would retain in an organization is 3 years. It means the retention rate of Gen. Y employees is higher in Srinlanka in comparison to Nepal. Job hoping tendency in Nepal The first five reasons that influences Millennial to hope the job are for seeking better opportunities, low pay structure, no any perspective of growth, low job securities and unfair treatment of management. Similarly, the study in Srilanka showed the first five reasons that influence employees to hop job are pay package, career growth, working environment and culture, reputation of the organization and job security (Thennakoon, 2014). It means the reasons behind hopping job in Srilanks and Nepal are quite similar because both countries are developing countries and tendency of the millennial is similar.

In the case of gender, the job hopping was found more in males in comparison to female. Females are more likely to hop the job in the beginning of the career until they fit into the job whereas males are found 
to be hopping the job throughout their career. In the case of marital status, the married respondents have low rate of job hopping than unmarried ones. It is because the married respondents had more obligations towards the family.

\section{Implications}

\section{Managerial implication}

Since this is one of the first kind of research on job hopping tendencies in Nepal, it can be widely used by HR managers to retain employees in their organizations. Employee retention has been one of the major problem in Nepalese organizations. Since this study showed the people who are more likely to hop jobs and the reason behind their job hopping, managers can use the results to formulate HR policies. However, since this study is only based on the study of Millennial and their trend of job hopping, it cannot be generalized to overall job market.

\section{Future research implication}

This research focused on the millennial living in Kathmandu valley only. The future research can be extended to other cities of Nepal. Similarly, the sample selected for this study is only 200 respondents. The future researcher can conduct the similar research by increasing the sample size to get more valid research.

\section{References}

Krishnan, T., Miranda, J., \& Siddiq, M. S. (2014). Factors influencing high turnover in multinational call centres in Malaysia. Journal of Business and Management,5: 1-10.

Lee, T. W., Mitchell, T. R., Sablynski, C. J., Burton, J. P., \&Holtom, B. C. (2004). The effects of job embeddedness on organizational citizenship, job performance, volitional absences, and voluntary turnover. Academy of Management Journal, 47(5), 711-722.

March, J. G., \& Simon, H. A. (1958). Organizations. New York: Wiley.

Maertz, C.P. \& Griffeth, R. (2004). 25 year's voluntary turnover research: a review and critique. Wiley, 17: 49-81.

Maertz, C.P. \& Griffeth, R (2004). Eight motivational forces and voluntary turnover: a theoretical synthesis with implications for research. Journal of Management, 30(5): 667-683.

Mitchell, T.R., Holton , B.C., Bruton, J.C. \& Sablynski, C.J. (2004). A multilevel investigation of leadership and turnover behavior. Journal of Management, 41(6): 1724-1744.

Mitchell, T. R., Holtom, B. C., Lee, T. W., Sablynski, C. J., \& Erez, M. (2001). Why people stay: Using job embeddedness to predict voluntary turnover. Academy of Management Journal, 44(6), 1102-1121.

Porter, L. w., \& Steers, R. M. (2003). Motivation and work behaviour. Mumbai, McGraw-Hill.

Thennakoon, D. (2014). An exploratory study on job hopping in Sri Lanka: a study on generation 'Y' employees. 9th International Research Conference on Management and Finance, At Colombo, Sri Lanka. Colombo 